\title{
La classification des méthodes de chasse
}

Alain Testart

\section{OpenEdition}

Journals

Édition électronique

URL : https://journals.openedition.org/tc/1012

DOI : $10.4000 /$ tc. 1012

ISSN : 1952-420X

\section{Éditeur}

Éditions de l'EHESS

\section{Édition imprimée}

Date de publication : 1 juin 1984

ISSN : 0248-6016

\section{Référence électronique}

Alain Testart, "La classification des méthodes de chasse », Techniques \& Culture [En ligne], 3 | 1984, mis en ligne le 26 janvier 2006, consulté le 29 septembre 2022. URL : http://journals.openedition.org/ tc/1012 ; DOI : https://doi.org/10.4000/tc.1012

Ce document a été généré automatiquement le 29 septembre 2022

Tous droits réservés 


\section{La classification des méthodes de chasse}

Alain Testart 